\title{
Avermectins residues in milk produced in the state of Pernambuco
}

\author{
Patrícia Marinho MÜLLER ${ }^{1 *}$ (D), Elizabeth Sampaio de MEDEIROS ${ }^{1}$, Rinaldo Aparecido MOTA ${ }^{1}$, \\ Maria Betânia de Queiroz ROLIM ${ }^{1}$, Marcos Vinícius COLOMBO ${ }^{2}$, Gabriel RÜBENSAM ${ }^{2}$, Fabiano BARRETO², \\ Daniel Dias da SILVA ${ }^{1}$, Tamyres Izarelly Barbosa da SILVA ${ }^{3}$
}

\begin{abstract}
Milk is a food widely consumed by the population, so it is important that it has adequate hygienic conditions and is free of chemical contaminants from various sources. This study aimed to evaluate the occurrence of avermectin residues in milk produced in the state of Pernambuco. The collections were performed in the dry and rainy season, being collected 60 and 48 samples, respectively, which were analyzed in the National Agricultural Laboratory of Rio Grande do Sul by liquid chromatography coupled with mass spectrometry. In the dry period, $46.7 \%$ (28/60) of samples with avermectin residues above the Limit of Detection (LD), 1.7\% (01/60) with levels above the Quantifiable Limit (QL) and 51.6\% (31/60) did not detect any residues. In the rainy season, $6.25 \%(03 / 48)$ presented residues above $\mathrm{LD}$ and in $93.75 \%(45 / 48)$ of samples there was no detection of residues. No samples were detected with amounts of avermectins above the Maximum Residue Limit in this study. The milk evaluated did not expose high risks to the health of the population, due to the low level of residues present. However, veterinary drug residue monitoring data are essential for assessing human exposure to these compounds.
\end{abstract}

Keywords: antiparasitics; dairy cattle; food safety; maximum residues limit.

Practical Application: Detection of avermectin residues in milk.

\section{Introduction}

Milk is among the most important products of Brazilian agriculture and its derivatives play a relevant role in the food supply and the generation of jobs and income for the population (Hemme \& Otte, 2010). The Northeast region is responsible for approximately $5 \%$ of all bovine milk produced in the country (Instituto Brasileiro de Geografia e Estatística, 2013). The State of Pernambuco currently produces about 1.6 million liters per day (Instituto Agronômico de Pernambuco, 2014).

Milk production is constantly growing, however, dairy producers still use unskilled methods, resulting in a poor quality raw material (Correa et al., 2009). The control of parasites in cattle is an important factor in production, since they cause great economic losses due to reduced productivity (Villa-Mancera \& Reynoso-Palomar, 2019) and pathogen transmission, which can lead to death of animals (Delgado et al., 2009).

There are approximately 1,500 medicines licensed by the Ministério da Agricultura, Pecuária e Abastecimento for use in Brazilian cattle. Among these, the therapeutic class with the largest number of medications are antiparasitic (ectoparasiticides, endoparasiticides and endectocides), with just over 400 items (Junquera et al., 2019). Among these formulations, 127 contain avermectins in their composition, whether abamectin, doramectin, eprinomectin, ivermectin or moxidectin (Bushra et al., 2019, Prichard \& Geary, 2019). These avermectins represent over $35 \%$ of all parasitic drugs marketed in the country (Pacheco-Silva et al., 2014).

The preference for avermectins is probably a consequence of their extended endectocidal activity and due to the slow elimination rates of these compounds in cattle. However, the higher persistence of these compounds in the body may also lead to the presence of residues in animal foods at levels above the Maximum Residues Limit (MRL) set up by the different countries, causing undesirable public health risks associated with its consumption (Rübensam et al., 2013; Li et al., 2015; Silva et al., 2017).

The elimination of pharmacological residues and their metabolites in milk may have negative effects on human health (Beltrán et al., 2018), since in addition to triggering the phenomenon of parasitic resistance, the drugs used may have genotoxic and/or teratogenic effects (European Medicines Agency, 2002; Jafari et al., 2019). The pasteurization, boiling and sterilization processes of milk does not eliminate the residues of avermectins from this food (Forsythe, 2002; Imperiale et al., 2009). Although they pose a health hazard to the population, the presence of drug residues in food needs to be further studied to determine the real risk to the population from consuming contaminated food (International Dairy Federation, 2013).

In order to achieve greater safety in milk consumption, it is necessary to establish food safety policies and control of

${ }^{2}$ Laboratório Nacional Agropecuário/RS, Porto Alegre, RS, Brasil

${ }^{3}$ Universidade Federal do Acre - UFAC, Rio Branco, AC, Brasil

${ }^{*}$ Corresponding author: patricia.muller@agricultura.gov.br 
these residues in milk and dairy products (Garcia et al., 2019). Federal government agencies have established programs to verify the presence of such residues in food of animal origin for human consumption (Agência Nacional de Vigilância Sanitária, 2003). However, not all states in Brazil can be covered by the programs. Thus, the objective of this study was to evaluate the occurrence of avermectin residues in milk produced in the state of Pernambuco.

\section{Materials and methods}

A survey of pasteurized dairy producers and UHT (ultra high temperature) in the state of Pernambuco. Information about existing trademarks was obtained from the Ministério da Agricultura, Pecuária e Abastecimento (MAPA) and Agência de Defesa e Fiscalização Agropecuária de Pernambuco to identify which companies had inspection services in their respective agencies (Federal Inspection Service - F.I.S. and State Inspection Service - S.I.S.).

Thus, 75 milk samples were collected with F.I.S and 33 with S.I.S., totaling 108 samples. From each brand, a minimum of six samples and a maximum of 12 samples were collected from the retail food retailers in their sealed primary packaging. The collections were performed in two periods: dry (60 samples) and rainy (48 samples), with rainfall indexes between $370 \mathrm{~mm}^{3}$ to $1.600 \mathrm{~mm}^{3}$ and $267 \mathrm{~mm}^{3}$ to $4.500 \mathrm{~mm}^{3}$, respectively (Instituto Agronômico de Pernambuco, 2015).

Each milk sample collected was fractionated and packed in sterile $50 \mathrm{ml}$ plastic vials, remaining frozen at $-18^{\circ} \mathrm{C}$ until processing. The samples were packed in an isothermal box and transported frozen by air to Laboratório Nacional Agropecuário (LANAGRO/ RS) for analysis according to the official methods of the MAPA.

For the determination of avermectin residues in bovine milk, $5 \mathrm{~mL}$ of milk was used following the Test Method, advocated by MAPA. The milk samples were submitted to the extraction process with organic solvent (acetonitrile) to obtain a purified extract, going through the freezing and evaporation clean-up step. The final extracts were analyzed by liquid chromatography coupled to mass spectrometry. Results were expressed as Detectable Limits (DL) and Quantifiable Limits (QL) of residues, being $1.0 \mu \mathrm{g} / \mathrm{L}$ and $2.5 \mu \mathrm{g} / \mathrm{L}$, respectively. The drugs evaluated belonged to the macrocyclic lactone classes (abamectin - ABA; doramectin - DOR; eprinomectin - EPR; ivermectin - IVE; moxidectin - MOX).

Statistical analysis was performed by calculating absolute and relative frequency (Sampaio, 1998) and Fisher's Exact test to compare the results obtained between the two periods analyzed.

\section{Results and discussion}

In this study, 10 milk brands were identified, six with F.I.S. and four with S.I.S. Milk-processing dairy products with F.I.S. were located in the municipalities of Agreste Pernambucano: Bom Conselho, Garanhuns, Pedra and São Bento do Uma. Já os que possuem S.I.S. Those with S.I.S. were located in the municipalities of the Agreste region and Zona da Mata: Bom Conselho, Pesqueira, Serra Talhada and Lagoa de Itaenga.

In the dry period, $46.7 \%(28 / 60)$ of samples with residues above DL and $1.7 \%(01 / 60)$ with levels above QL were obtained. No residue was detected in $51.6 \%(31 / 60)$ of the samples. In the rainy season, $6.25 \%(03 / 48)$ of the samples presented avermectin residues above the DL. No sample presented residues above the QL. In $93.75 \%$ (45/48) of the samples collected in the rainy season there was no detection of residues (Table 1).

When there is a comparison regarding the presence (above DL and QL) and absence (Undetectable Limit) of avermectins in milk between the collections performed, in the dry and rainy period, it is clear that there is a significant association $(\mathrm{p}=0.05)$ between the analyzed periods. Milk samples collected in the dry season were more likely to contain avermectin residues than those produced in the rainy season.

The control of endoparasites, in general, in Brazil, is performed at the driest time of the year where pastures are low and at their earliest moment of development. Thus, the larvae cannot survive in the natural environment, occurring a larger population of parasites in the animals, making this period the most conducive to their control through the use of antiparasitics (Carvalho et al., 2003, Simões et al., 2010).

It is possible that a larger amount of milk samples with avermectin residues were detected in the dry period as this is the most suitable period for deworming in animals. In addition, during November, (the period considered dry in this region) when the foot-and-mouth vaccination takes place, (Brasil, 2014a), there is usually an opportunity for producers to deworm their animals, and the two concomitant actions prevent unnecessary management in the herd.

During the collection period, the on-site sanitary management of lactating cows reared on the property of one of the S.I.S. dairy farms was monitored. and their milk was analyzed. Antiparasitic use was found throughout the year, with the active ingredient IVE, being used in an attempt to control ticks. In all the samples collected from this dairy product, a total of six, three in each period studied, there contained IVE residues, including the only sample from the study in which residue detection above QL was obtained.

Considering the total samples studied in both periods, it was observed that $70.37 \%(76 / 108)$ of them did not detect avermectin residues. Already $28.07 \%(31 / 108)$ of the samples showed residues of avermectins in amounts above the DL, but

Table 1. Analysis of avermectin residues in milk samples produced in the state of Pernambuco during the dry and rainy period.

\begin{tabular}{|c|c|c|c|}
\hline & \multicolumn{3}{|c|}{ Avermectin Residues } \\
\hline & & Period & Rainy Period \\
\hline \multirow[t]{2}{*}{ Presence $^{1}$} & QL & $1.7 \%(01)$ & $0 \%(0)$ \\
\hline & DL & $46.7 \%(28)$ & $6.25 \%(03)$ \\
\hline Absence $^{2}$ & & $51.6 \%(31)$ & $93.75 \%(45)$ \\
\hline Total & & $100 \%(60)$ & $100 \%(48)$ \\
\hline
\end{tabular}


below the QL. Only $0.93 \%(1 / 108)$ of the samples was above the QL. No samples were detected with avermectins above MRL (Table 2). Thus, all samples analyzed meet the standards established by Legislation for the presence of avermectin residues in milk. (Brasil, 2009b).

However, considering the occurrence of avermectin residues in milk marketed in the domestic market, although below the maximum limits established by the norm in most cases, this food should be considered as an important source of human exposure to these residues (Rübensam, 2010). Most products of animal origin detected with chemical residues have a low concentration of residues, which during a single or a few exposures may cause adverse health effects (Beltrán et al., 2018). However, milk is present in human food from childhood to the last days of life, being one of the most consumed foods, exposing the population constantly to the residues present in this food. This fact increases the importance of research regarding the problems that this frequent exposure can cause to the health of consumers (Picinin, 2013).

Regarding the different groups of avermectins analyzed, it was observed that EPR was not detected in any of the samples, both in the dry and rainy periods (Table 3 ). The use of eprinomectin is permitted and its MRL in milk is $20 \mu \mathrm{g} / \mathrm{L}$. This substance maintains the same antiparasitic activities as avermectins and, as it is more hydrophilic, is less likely to appear in milk. This led to the use of EPR in dairy cattle. (Holste et al., 1997, Hunter et al., 2013).

However, although permissible MRLs are defined by international criteria, there are substances that are contraindicated in lactating animals, but nonetheless they are accepted in these programs in a contradictory manner (Durden \& Wotske, 2009). The use of ABA and DOR is not authorized for lactating cows, so milk cannot contain residues of them; however their MRLs are $10 \mu \mathrm{g} / \mathrm{L}$ and $15 \mu \mathrm{g} / \mathrm{L}$ (Brasil, 2006). In this study we identified a sample with residual amount of DOR above DL in the dry period (Table 3). Considering the non-authorization of the use of this substance in lactating cows, the sample should be violated, however only quantities of the substance that exceeded MRL were characterized as violations and unfit for consumption.

The IVE was the most detected substance in the 108 samples of this study being present in 30 of them $(27,77 \%)$, including, presenting amounts of residue above the QL in a sample $(0,93 \%)$ collected in the dry period (Table 3 ). In the rainy season, IVE was detected only with residues above DL. The use of ivermectin is allowed and its MRL in milk is $10 \mu \mathrm{g} / \mathrm{L}$ (Ni et al., 2019). However, product labels containing ivermectin do not recommend use in lactating cows (Brasil, 2006), this being another contradiction between what is allowed and not allowed.

Table 2. Avermectin residues in milk samples produced in the state of Pernambuco.

\begin{tabular}{lc}
\hline & Avermectin \\
\hline Not detectable & $70.37 \%(76 / 108)$ \\
Detectable & $28.07 \%(31 / 108)$ \\
Quantifiable & $0.93 \%(1 / 108)$ \\
Maximum Residues Limit & $0(0 \%)$ \\
\hline
\end{tabular}

It is emphasized that milks containing IVE residues should not be intended for human consumption due to toxicological reasons (Chicarino, 2007; Türkan et al., 2018). The lipophilic character of the IVE molecule provides its permanence in the body for long periods (Rübensam et al., 2013) and presence in milk is indicative of a lack of good veterinary practice. Based on this finding, and according to European Community recommendations, ivermectin should be banned for use in dairy cows (Jesus, 2007).

Lobato et al. (2006) collected 168 samples of pasteurized and UHT milk from 1999 to 2001 in supermarkets in Campinas-SP and in the metropolitan region of Rio de Janeiro-RJ to investigate the presence of IVE. They found residues of the substance in concentrations above the QL $(2.0 \mu \mathrm{g} / \mathrm{L})$ in $17.8 \%(30 / 168)$ of the samples, reaching a concentration of $07 \mu \mathrm{g} / \mathrm{L}$, close to the MRL stipulated by Brazilian legislation, but not above this limit. Although the milk samples were already collected from their ready-to-eat primary packaging, in accordance with our research, the Plano Nacional de Controle de Resíduos e Contaminantes (PNCRC) was not a current program in Brazil, and perhaps for this reason the frequency of samples with higher residue levels has been verified. In addition, the QL of the laboratory responsible for the analyzes performed was lower than that used in the present study and probably for this reason the percentage of avermectins was lower.

On the other hand, Jesus (2007) analyzed 157 pasteurized whole milk samples collected in the Paraná State dairy basin and found that $39 / 157$ (25\%) of the samples did not contain any of the avermectin residues which were studied (ABA, DOR, IVE e EPR). However, the presence of EPR residues was detected in two samples, ABA in 27, DOR in 31 and IVE in 107. Of the 157 samples analyzed, $65 \%$ were in accordance with the legislation and $35 \%$ were in disagreement. (Brasil, 2006). Of the samples in disagreement, $100 \%$ were disapproved for containing prohibited avermectins (ABA and DOR) for lactating cows. However, no sample showed residue values above the MRL.

In Minas Gerais, Picinin (2013) researched 42 different substances, including avermectins in 132 raw milk samples collected from 45 dairy farms and detected the presence of $\mathrm{ABA}$ in $07 / 132(5.3 \%)$ samples and one of them had residue levels above the MRL.

Between 2002 and 2007 Agência nacional de Vigilância Sanitária (ANVISA), through the Programa de Análises de Resíduos de Medicamentos Veterinários em Alimentos (PAMVet), analyzed samples of UHT, powdered and pasteurized milk to verify the occurrence of avermectin residues. Only in 2006 and 2007, 8\% (48/603) of the analyzed samples presented doramectin residues above the established MRL, being, therefore, violated samples and the milk unfit for consumption (Agência Nacional de Vigilância Sanitária, 2005, 2006, 2009). The only northeastern state that had milks analyzed in the program was Bahia (Agência Nacional de Vigilância Sanitária, 2009). Thus, there is no information on the occurrence of veterinary drug residues in milk produced in the state of Pernambuco and consumed by the local population.

The MAPA, through the PNCRC, since 2006 it has been analyzing the presence of residues of avermectins and other 
Table 3. Residues of different avermectins in milk samples produced in the state of Pernambuco during the dry and rainy period.

\begin{tabular}{|c|c|c|c|c|c|}
\hline & & UL & $\mathrm{DL}$ & QL & Total \\
\hline \multirow[t]{2}{*}{$\mathrm{ABA}$} & $\mathrm{D}$ & $100 \%(60)$ & 0 & 0 & $100 \%(60)$ \\
\hline & $\mathrm{TP}$ & $100 \%(108)$ & 0 & 0 & $100 \%$ \\
\hline \multirow[t]{2}{*}{ DOR } & $\mathrm{D}$ & $98.3 \%$ (59) & $1.7 \%(01)$ & 0 & $100 \%(60)$ \\
\hline & $\mathrm{R}$ & $100 \%(48)$ & 0 & 0 & $100 \%(48)$ \\
\hline \multirow[t]{3}{*}{ EPR } & $\mathrm{D}$ & $100 \%(60)$ & 0 & 0 & $100 \%(60)$ \\
\hline & $\mathrm{R}$ & $100 \%(48)$ & 0 & 0 & $100 \%(48)$ \\
\hline & $\mathrm{TP}$ & $100 \%(108)$ & 0 & 0 & $100 \%$ \\
\hline IVE & $\mathrm{D}$ & $53.3 \%(32)$ & $45 \%(27)$ & 1. (01) & $100 \%(60)$ \\
\hline \multirow{2}{*}{ MOX } & $\mathrm{R}$ & $100 \%(48)$ & 0 & 0 & $100 \%(48)$ \\
\hline & $\mathrm{TP}$ & $100 \%(108)$ & 0 & 0 & $100 \%(108)$ \\
\hline
\end{tabular}

UL - Undetectable Limit; DL - Detectable Limits; QL - Quantifiable Limits; D - Dry Period; R - Rainy Period; TP - Total Period; ABA - Abamectin; DOR - Doramectin; EPR - Eprinomectin; IVE - Ivermectin; MOX -Moxidectin.

substances in raw, processed (F.I.S.) milk and powdered milk. In 2006, 2007 and 2008, avermectin residues above MRL were detected in $4.8 \%(06 / 125), 1.16 \%(01 / 86)$ and $4.38 \%(05 / 114)$ of the samples. analyzed respectively. Between 2009 and 2013, no sample among the 640 analyzed showed avermectin levels above the MRL (Brasil, 2007, 2008, 2009a, 2010, 2011, 2012, 2013, 2014b).

Monitoring data on veterinary drug residues is important to assess human exposure to these compounds, as the results of the official programs of the Brazilian Government and other research show that the use of avermectins over the years has been observed. In lactating cows it is a common practice, despite the manufacturers' indication of non-use in lactating animals or that the withdrawal periods indicated for each substance are met. Thus, the development of new research is important, as well as the maintenance and expansion of government programs to determine the possible damage to the population's health.

\section{Conclusion}

The results of this study indicate that during the dry season the probability of obtaining milk with avermectin residues is higher. However, even milk produced in the driest period does not cause high risks to consumer health due to the low amount of avermectin residues present, below the MRLs advocated by various world agencies.

\section{Acknowledgements}

To the Coordenação de Aperfeiçoamento de Pessoal de Nível Superior (CAPES) and to the Laboratório Nacional Agropecuário (LANAGRO/RS).

\section{References}

Agência Nacional de Vigilância Sanitária - ANVISA. (2003). Programa Nacional de Análise de Resíduos de Medicamentos Veterinários em Alimentos Expostos ao Consumo - PAMVet. Brasília: ANVISA.

Agência Nacional de Vigilância Sanitária - ANVISA. (2005). Programa de Análise de Resíduos de Medicamentos Veterinários em Alimentos de Origem Animal - PAMVet. Relatório 2002/2003 - Monitoramento de Resíduos em Leite Exposto ao Consumo ( $1^{\circ}$ e $2^{\circ}$ anos de atividades). Brasília: ANVISA.

Agência Nacional de Vigilância Sanitária - ANVISA. (2006). Programa de Análise de Resíduos de Medicamentos Veterinários em Alimentos de Origem Animal - PAMVet. Relatório 2004/2005 - Monitoramento de Resíduos em Leite Exposto ao Consumo ( $3^{\circ}$ e $4^{\circ}$ anos de atividades). Brasília: ANVISA.

Agência Nacional de Vigilância Sanitária - ANVISA. (2009). Programa de Análise de Resíduos de Medicamentos Veterinários em Alimentos de Origem Animal - PAMVet. Relatório 2006/2007 - Monitoramento de Resíduos em Leite Exposto ao Consumo ( $5^{\circ}$ e $6^{\circ}$ anos de atividades). Brasília: ANVISA.

Beltrán, M. C., Morari-Pirlog, A., Quintanilla, P., Escriche, I., \& Molina, M. P. (2018). Influence of enrofloxacin on the coagulation time and the quality parameters of goat's milk yoghurt. International Journal of Dairy Technology, 71(1), 105-111. http://dx.doi.org/10.1111/14710307.12388 .

Brasil. Ministério da Agricultura, Pecuária e Abastecimento. (2006). Programas de Controle de Resíduos em Carne (Bovina, Aves, Suína e Eqüina), Leite, Mel, Ovos e Pescado (Portaria n 50, de 20 de fevereiro de 2006). Diário Oficial [da] República Federativa do Brasil. Retrieved from http://www.agricultura.gov.br

Brasil. Ministério da Agricultura, Pecuária e Abastecimento. (2007). Programas de Controle de Resíduos e Contaminantes em Carnes (Bovina, Aves, Suína e Equina), Leite, Mel, Ovos e Pescado (IN n ${ }^{\circ}$ 08, de 30 de março de 2007). Diário Oficial [da] República Federativa do Brasil. Retrieved from http://www.agricultura.gov.br 
Brasil. Ministério da Agricultura, Pecuária e Abastecimento. (2008). Programas de Controle de Resíduos e Contaminantes em Carnes (Bovina, Suína, Aves e Eqüina), Leite, Ovos, Mel e Pescado (IN no 09, de 10 de abril de 2008). Diário Oficial [da] República Federativa do Brasil. Retrieved from http://www.agricultura.gov.br

Brasil. Ministério da Agricultura, Pecuária e Abastecimento. (2009a). Programas de Controle de Resíduos e Contaminantes em Carnes (Bovina, Suína, Aves e Eqüina), Leite, Ovos, Mel e Pescado (IN n ${ }^{\circ}$ 15, de 25 de maio de 2009). Diário Oficial [da] República Federativa do Brasil. Retrieved from http://www.agricultura.gov.br

Brasil. Ministério da Agricultura, Pecuária e Abastecimento. (2009b). Plano Nacional de Controle de Resíduos e Contaminantes. Brasília: DAS/MAPA.

Brasil. Ministério da Agricultura, Pecuária e Abastecimento. (2010). Programas de Controle de Resíduos e Contaminantes em Carnes (Bovina, Suína, Aves e Equina), Leite, Ovos, Mel e Pescado (IN n ${ }^{\circ}$ 06, de 16 de março de 2010). Diário Oficial [da] República Federativa do Brasil. Retrieved from http://www.agricultura.gov.br

Brasil. Ministério da Agricultura, Pecuária e Abastecimento. (2011). Programas de Controle de Resíduos e Contaminantes em Carnes (Bovina, Suína, Aves e Equina), Leite, Ovos, Mel e Pescado (IN $\mathrm{n}^{\circ}$ 06, de 25 de fevereiro de 2011). Diário Oficial [da] República Federativa do Brasil. Retrieved from http://www.agricultura.gov.br

Brasil. Ministério da Agricultura, Pecuária e Abastecimento. (2012). Programas de Controle de Resíduos e Contaminantes em Carnes (Bovina, Suína, Aves e Equina), Leite, Ovos, Mel e Pescado (IN n ${ }^{\circ}$ 07, de 04 de abril de 2012). Diário Oficial [da] República Federativa do Brasil. Retrieved from http://www.agricultura.gov.br

Brasil. Ministério da Agricultura, Pecuária e Abastecimento. (2013). Programas de Controle de Resíduos e Contaminantes em Carnes (Bovina, Suína, Aves e Equina), Leite, Ovos, Mel e Pescado (IN n ${ }^{\circ}$ 07, de 27 de março de 2013). Diário Oficial [da] República Federativa do Brasil. Retrieved from http://www.agricultura.gov.br

Brasil. Ministério da Agricultura, Pecuária e Abastecimento. (2014a). Calendário nacional de vacinação dos bovinos e bubalinos contra a febre aftosa. Retrieved from http://www.agricultura.gov.br/ campanha-aftosa

Brasil. Ministério da Agricultura, Pecuária e Abastecimento. (2014b). Programas de Controle de Resíduos e Contaminantes em Carnes (Bovina, Suína, Aves e Equina), Leite, Ovos, Mel e Pescado (Portaria $\mathrm{n}^{\circ}$ 60, de 07 de maio de 2014). Diário Oficial [da] República Federativa do Brasil. Retrieved from http://www.agricultura.gov.br

Bushra, M., Shahardar, R. A., Allaie, I. M., \& Wani, Z. A. (2019). Efficacy of closantel, fenbendazole and ivermectin against GI helminths of cattle in central Kashmir. Journal of Parasitic Diseases: Official Organ of the Indian Society for Parasitology, 43(2), 289-293. http://dx.doi. org/10.1007/s12639-019-01091-w. PMid:31263335.

Carvalho, L. A., Novaes, L. P., Gomes, A. T., Miranda, J. E. C., \& Ribeiro, A. C. C. L. (2003). Sistemas de produção de leite (Zona da Mata Atlântica). Brasília: Embrapa Gado de Leite. Retrieved from http://sistemasdeproducao.cnptia.embrapa.br/FontesHTML/Leite/ LeiteZonadaMataAtlantica/manejo.html\#verminose

Chicarino, L. R. D. (2007). Programa Nacional de Controle de Resíduo: regulamentação e implantação gradativa (Monografia de especialização). Instituto Qualittas de Pós-graduação, Universidade Castelo Branco, Brasília.

Correa, C. P. A., Ribas, M. M. F., \& Madrons, G. S. (2009). Avaliação das condições higiênico sanitárias do leite cru em pequenas propriedades do município de Bom Sucesso- PR. Revista Brasileira de Tecnologia Agroindustrial, 3, 21-28.
Delgado, F. E., Lima, Wdos. S., Cunha, A. P., Bello, A. C., Domingues, L. N., Wanderley, R. P., Leite, P. V., \& Leite, R. C. (2009). Verminoses dos bovinos: percepção de pecuaristas em Minas Gerais, Brasil. Revista Brasileira de Parasitologia Veterinária, 18(3), 29-33. http:// dx.doi.org/10.4322/rbpv.01803005. PMid:19772773.

Durden, D. A., \& Wotske, J. (2009). Quantitation and validation of macrolide endectocides in raw milk by negative ion electrospray MS/MS. Journal of AOAC International, 92(2), 580-596. http:// dx.doi.org/10.1093/jaoac/92.2.580. PMid:19485219.

European Medicines Agency - EMEA. (2002). Position paper on the establishment of MRLs for milk considering the daily intake by children European Medicines Agency. Amsterdam: Committee for Veterinary Medicinal Products.

Forsythe, S. J. (2002). Microbiologia da segurança alimentar. Resíduos de produtos de uso veterinário. Porto Alegre: Artemed.

Garcia, S. N., Osburn, B. I., \& Cullor, J. S. (2019). A one health perspective on dairy production and dairy food safety. One Health, 7, 1-9. http:// dx.doi.org/10.1016/j.onehlt.2019.100086. PMid:30911596.

Hemme, T., \& Otte, J. (2010). Status and prospects for smallholder milk production - a global perspective. Rome: Food and Agriculture Organization of the United Nations.

Holste, J. E., Smith, L. L., Hair, J. A., Lancaster, J. L., Lloyd, J. E., Langholff, W. K., Barrick, R. A., \& Eagleson, J. S. (1997). Eprinomectin: a novel avermectin for control of lice in all classes of cattle. Veterinary Parasitology, 73(1-2), 153-161. http://dx.doi.org/10.1016/S03044017(97)00063-0. PMid:9477501.

Hunter, J. S., 3rd., Yoon, S., Yazwinski, T. A., Williams, J. C., \& Rehbein, S. (2013). The efficacy of eprinomectin extended-release injection against naturally acquired nematode parasites of cattle, with special regard to inhibited fourth-stage Ostertagia larvae. Veterinary Parasitology, 192(4), 346-352. http://dx.doi.org/10.1016/j.vetpar.2012.11.041. PMid:23273781.

Imperiale, F. A., Farias, C., Pis, A., Sallovitz, J. M., Lifschitz, A., \& Lanusse, C. (2009). Thermal stability of antiparasitic macrocyclic lactones Milk residues during industrial processing. Food Additives and Contaminants, 26(1), 57-62. http://dx.doi.org/10.1080/02652030802322879. PMid:19680871.

Instituto Agronômico de Pernambuco - IPA. (2014). Assessoria de Comunicação - Clipping Eletrônico. Retrieved from http://www.ipa.br/ novo/arquivos/clipping/03062014114017139-clipping-03-06-14.pdf

Instituto Agronômico de Pernambuco - IPA. (2015). Sessão de Índices Pluviométricos. Retrieved from http://www.ipa.br/indice_pluv.php

Instituto Brasileiro de Geografia e Estatística - IBGE. (2013). Estatística de Produção Pecuária. Retrieved from http://www.ibge.gov.br/home/ estatistica/indicadores/agropecuaria/producaoagropecuaria/abateleite-couro-ovos_201302_publ_completa.pdf

International Dairy Federation - IDF. (2013). Identification and assessment of emerging issues associated with chemical contaminants in dairy products. Bulletin of the International Dairy Federation. Retrieved from http://www.fil-idf.org/Public/PublicationsPage. php?ID=27121\#list

Jafari, S., Dehghani, M., Nasirizadeh, N., \& Baghersad, M. H. (2019). Synthesis and characterisation of a selective adsorbent based on the molecularly imprinted polymer for the removal of cloxacillin antibiotic residue from milk. International Journal of Dairy Technology, 72(4), 505-514. http://dx.doi.org/10.1111/1471-0307.12620.

Jesus, D. A. (2007). Determinação de resíduos de avermectinas no leite por CLAE-EM/EM (Dissertação de mestrado). Universidade Federal do Paraná, Curitiba. 
Junquera, P., Hosking, B., Gameiro, M., \& Macdonald, A. (2019). Benzoylphenyl ureas as veterinary antiparasitics. An overview and outlook with emphasis on efficacy, usage and resistance. Parasite (Paris, France), 26(26), 1-33. http://dx.doi.org/10.1051/ parasite/2019026. PMid:31041897.

Li, X., Wang, M. M., Zheng, G. Y., Ai, L. F., \& Wang, X. S. (2015). Fast and online determination of five avermectin residues in foodstuffs of plant and animal origin using reusable polymeric monolithic extractor coupled with LC-MS/MS. Journal of Agricultural and Food Chemistry, 29(63), 16, 4096-4103. http://dx.doi.org/10.1021/ acs.jafc.5b00739. PMid:25865176.

Lobato, V., Rath, S., \& Reyes, F. G. R. (2006). Occurrence of ivermectina in bovine milk from the Brazilian retail market. Food Additives and Contaminants, 23(7), 668-673. http://dx.doi. org/10.1080/02652030600627206. PMid:16751143.

Ni, T., Peng, D., Wang, Y., Pan, Y., Xie, S., Chen, D., Wang, Y., Tao, Y., \& Yuan, Z. (2019). Development of a broad-spectrum monoclonal antibody-based indirect competitive enzyme-linked immunosorbent assay for the multi-residue detection of avermectins in edible animal tissues and milk. Food Chemistry, 286, 234-240. http://dx.doi. org/10.1016/j.foodchem.2019.02.011. PMid:30827601.

Pacheco-Silva, E., Souza, J. R., \& Caldas, E. D. (2014). Resíduos de medicamentos veterinários em leite e ovos. Quimica Nova, 37(1), 111-122. http://dx.doi.org/10.1590/S0100-40422014000100020.

Picinin, L. C. A. (2013). Resíduos de produtos de uso veterinário e contaminantes em leite (Tese de doutorado). Universidade Federal de Santa Catarina, Florianópolis.

Prichard, R. K., \& Geary, T. G. (2019). Perspectives on the utility of moxidectin for the control of parasitic nematodes in the face of developing anthelmintic resistance. International Journal for Parasitology. Drugs and Drug Resistance, 10, 69-83. http://dx.doi. org/10.1016/j.ijpddr.2019.06.002. PMid:31229910.

Rübensam, G. (2010). Determinação dos resíduos de avermectinas e milbecinas em leite bovino por cromatografia líquida e detecção por fluorescência e espectrometria de massas (Dissertação de mestrado). Universidade Federal do Rio Grande do Sul, Porto Alegre.

Rübensam, G., Barreto, F., Hoff, R. B., \& Pizzolato, T. M. (2013). Determination of avermectin and milbemycin residues in bovine muscle by liquid chromatography-tandem mass spectrometry and fluorescence detection using solvent extraction and low temperature cleanup. Food Control, 29(1), 55-60. http://dx.doi.org/10.1016/j. foodcont.2012.05.075.

Sampaio, I. B. M. (1998). Estatística aplicada à experimentação animal. Belo Horizonte: Fundação de Ensino e Pesquisa em Medicina Veterinária e Zootecnia.

Silva, G. R. D., Lima, J. A., Souza, L. F., Santos, F. A., Lana, M. A. G., Assis, D. C. S., \& Cançado, S. V. (2017). Multiresidue method for identification and quantification of avermectins, benzimidazoles and nitroimidazoles residues in bovine muscle tissue by ultra-high performance liquid chromatography tandem mass spectrometry (UHPLC-MS/MS) using a QuEChERS approach. Talanta, 171, 307320. http://dx.doi.org/10.1016/j.talanta.2017.05.012. PMid:28551144.

Simões, R., Gentile, R., Rademaker, V., D’Andrea, P., Herrera, H., Freitas, T., Lanfredi, R., \& Maldonado, A. Jr (2010). Variation in the helminth community structure of Thrichomys pachyurus (Rodentia: Echimyidae) in two sub-regions of the Brazilian Pantanal: the effects of land use and seasonality. Journal of Helminthology, 84(3), 266-275. http://dx.doi.org/10.1017/S0022149X09990629. PMid:19849884.

Türkan, F., Huyut, Z., \& Atalar, M. N. (2018). The toxicological impact of some avermectins on human erythrocytes glutathione $\mathrm{S}$-transferase enzyme. Journal of Biochemical and Molecular Toxicology, 32(10), 1-7. http://dx.doi.org/10.1002/jbt.22205. PMid:30091233.

Villa-Mancera, A., \& Reynoso-Palomar, A. (2019). Prevalence, economic assessment, and risk factors of gastrointestinal nematodes infecting herds in tropical, dry and temperate climate regions in Mexico. Microbial Pathogenesis, 129, 50-55. http://dx.doi.org/10.1016/j. micpath.2019.01.043. PMid:30710671. 